\title{
The Gender Sensitivity of Political Parties in Indonesia and Asean Women Politicians Network in Realizing Community Development Programs
}

\author{
Vina Darvina Salviana Soedarwo \\ University of Muhammadiyah Malang \\ vina_salviana@yahoo.co.id
}

\begin{abstract}
Women are assumed to have more sensitivity on gender issues than men. It means that women are assumed to have more sensitivity to fight genders for their interests. However, the limited participation of women in politics is becoming a crucial issue since the political parties have not given serious attention to women resulting unfulfilling in the quotas of women in parliament. In addition to that, the limited number of politicians possessing gender sensitivity is still a bitter reality throughout the world. Based on previous researches, some of the prominent reasons underlying this issue are the low quantity and quality of women politicians, the lack of support from political party leaders, and patriarchy culture within the society. Currently in Indonesia, some female politicians have been able to take part as legislators or head of the region (executive), but the numbers are still limited. The network of women politicians throughout ASEAN has not shown any encouraging results. Women politicians are able to realise community development programs in their respective regions, and together with ASEAN women, politicians build the welfare of the people especially regarding with the issue of women and family interests.
\end{abstract}

Keywords: gender sensitivity, women, political education, community development

\section{INTRODUCTION}

The phenomenon of the low representation of women in DPRD and DPR of the Republic of Indonesia since the introduction of the quota of representation of women in the year 2003 turned out to prove that political parties in Indonesia have not been able to generate the female cadres. It is proven by the low percentage of female legislative candidate sound earnings and the number of seats at the general election in 2009 and the year 2014 [1]. Another reality in several provinces in Indonesia showed the above picture as studies conducted [2] that the representation of women in DPRD of West Kalimantan has not been distributed in 14 regencies/cities. The findings of [2] study concluded that the degree of representation of women's politics in West Kalimantan had not reached the quota of 30 per cent yet. Thus the low public awareness of the importance of women's involvement in politics resulted in the low level of social capital legislative candidates of the women legislature [3] shows the number of women who have become a member of the national representation in 2014-2019 has increased to 18 people out of 10 people in the year 20092014. However, it is not just the quantity prioritized but the quantity followed quality. [4] described the representation of women in Bali province reaching only five people or $9.0 \%$ of the quota; this proves that in the elections of 2014 representation of women has not yet reached the quota of $30 \%$ as mandated by the election law and political party. Kartika [5] assumed that the culture of Bali indeed unfamiliar gives the role of women to the public sector; besides this view another obstacle is the enthusiasm of the woman herself has not been too prominent.

In East Java province representation of women in Parliament of legislative members during the years 20142019 reached only $15 \%$, this is a study conducted [6]. She describes that the quota of $30 \%$ still has not been met from existing seats 100 . The main factors were the patriarchal culture among the stakeholders, political parties, women and community voters.

The research conducted [7] in Central Java province illustrated that the implementation of a quota of $30 \%$ representation of women in politics is generally not reached Parliament in Central Java. The failure to obtain the quota of $30 \%$ is due to the strong patriarchal culture that influences voters to give preference to men candidates. They believe that women candidates are considered unable to represent the people's aspirations, and the people poorly rate the performance of the female candidates.

Another study [8] about the level of involvement of women in politics can be influenced by the dominant factor namely the level of education. The active women in her involvement as activists of political parties because all the tasks delegated to women influenced by their education.

Other findings [9] of political education in political parties in the Eastern Java illustrates that both PDI-P, Golkar, PKS, PAN, Gerindra and the Democratic Party did not have an ideal political education model. Meanwhile, each political party believes that their model is the ideal one.

The results of the above research show that a $30 \%$ quota of women as members of the legislative body in the reform era has not yet be fulfilled even in some provinces experienced a decline in the quantity and quality.This fact needs to be studied. The turnout of women in Indonesia during 2014 based on statistical data of the political year 2016 described the turnout of women very significant, i.e. $93,153,933$ voters or $49.82 \%$ of a 
total of $186,575,617$ voters, this is a significant capital in support of the attainment of a quota of $30 \%$ representation of women in Parliament. Moreover, in the process of establishing of ASEAN community, it seems that Indonesian women politicians have not yet built strong networking with women politicians of another ASEAN countries. This can be examined through the five countries of ASEAN signed the Declaration on 26 August 2014 in Denpasar's "Transforming women's Political Participation into Active Citizens in Southeast Asia's" women politicians meeting in five countries with the theme's "Women in Political Leadership in Southeast Asia" as an effort to fight for gender equality in politics. The five countries are Indonesia, Malaysia, the Philippines, Cambodia and East Timor. Currently, women political activity in five countries are still struggling to increase the number of women elected and should prove capable of sitting in Parliament. The members of the networks realise that the representation of women in the political sphere is importance on increasing gender equality, freedom, human rights and democracy.

Ideally, in ASEAN countries, members of Parliament can support the women to meet the quota of $30 \%$. They are still facing the same problems that is not able to obtain a $30 \%$ quota and lack of gender sensitivity among politicians from various political parties. It is interesting to review due to some reasons. Therefore, it was interesting to be examined (1) Study the political education based on gender sensitivity among political parties in Indonesia and the impacts on the construction of cadres each, their constituents and communities. (2) How women politicians can realise community development programs in their respective regions and together with ASEAN women politicians build the welfare of the ASEAN community.

\section{METHOD}

The method used in this study is qualitative research based on the interpretative approach of collecting the data through observation, in-depth interviews, documentation and focus group discussion. The subjects of the research are the Executive Board and the cadres of Party Democracy struggle, the Prosperous Justice Party (PKS), and Golkar Party.

Data has been collected through observational techniques, interviews and documentaries which then were analysed with the first stage reduction data, display data and verify the conclusion or withdrawl.

\section{RESULT}

Political education conducted by PDI-P through political school programs by inviting several prominent figures to convey the topics on Socialization 4 pillars, Pancasila, the Indonesian Constitution 1945, and Bhineka Tunggal Ika. The constraint factor in the process of recruitment of women cadres are the most citizens of
East Java having Islam as their religion, where the enthusiasm they tend to party is rooted in Islam.

There are some steps during the process of PKS cadre recruitment. From cadre, the beginner can become a member of the young. Usually, younger members already are allowed to become Chairman of the branch, once it can be increased to associate members as the core cadres of the party. The next level is that the adult member must have memorised the Holy Qur'an recitation for six juzz. The other level is the expert members, i.e. Member who has passed the entire curriculum is usually qualified cadres who are in to be members of DPD.

Golkar cadre recruitment system use cell active system, where communities are acting switch on bottomup from the level of Rukun Tetangga and Rukun Warga. The method is a kind of training delivery through the granting of material and discussion of two-way traffic communications. Fast Movers Cadre (KPC) became the vital agent team for the recruitment of cadres. After the recruiting of cadres held, the parties would form a Group of Cadres (POKKAR). To create a professional cadre, Golkar chose two ways, i.e. the formation of discussion groups, and implementation of Training of Trainers (ToT).

The three political parties have been conducting political education with each model and further describe the process of cadre recruitment. Although PDI-P has a Department for the Affairs of women's empowerment, the PKS has the field of women, and Family Resilience, as well as Golkar, has a unity of Women perceived their impact Golkar has not been optimal. It means that special political education assumed that gender equality or involving gender issues does not exist, not optimal and affecting the male cadres yet.

Department of the Affairs of women empowerment in any design has not been able to encourage the representation of women with adequate numbers in the fulfilment of quotas of $30 \%$ in Parliament. Similarly with PKS, although the party has women and Family Resilience affairs, and has a mission to strengthen the family resilience of Indonesia, women have not been able to encourage and meet the representation of women in Parliament, but the family empowerment program has been carried out in various areas. Moreover, in its organisation, the Golkar, for example, as a quite old political party in Indonesia has not been able to improve the quantity of women's representation in Parliament.

Regarding the network of women politicians in ASEAN, there has been a declaration of 5 countries on the women issues. However, it has not been as fruitful as expected. Some female politicians Indonesia have already talked in international scope about the importance of ASEAN women strive for the resilience of families as stated by politicians from the PKS in the ASEAN Conference on Women in Politics in Kuala Lumpur, Malaysia year 2015. However, an international network among women politicians has not been able to produce the ASEAN community development programs that are more concrete. Each of the politicians is moving in its territory and has not made cooperation in building 
the ASEAN community that prioritises the interests of the women yet.

In General, the ASEAN community focuses on three main pillars, namely, Economic Security, Political Security and Socio-Culture Community. What about the participation of women politicians have been unanimous in the ASEAN network of women politicians? There hasn't been a real form of realisation of their commitment to building the pillars that proclaimed in building the ASEAN community, the contribution of women politicians is still not adequate.

The above results of this study agree with Wollack [1] stating that the actual political parties are the primary and direct institution can be used by women cadres to seize the office of elected political leadership. Therefore, values, structure, policy and practice in political parties have profound consequences associated with the level of involvement of women in its membership in the Parliament or executive leadership. Political parties will gain more power when women take part in the election and become leaders without being able to influence the policies. The establishment of the Division of women without authority or the selection of women candidates in the list as a formality are some of the prominent emerging issues. Moreover, the Indonesian politics is still facing the marginalisation of women leaders, putting women in the area of possible election defeat; or remove a woman candidate would probably win is an attempt to "half a hearted" in improving the quantity and quality of participation of women in political life.

This condition was exacerbated by the lack of political education for the members of a political party for women. Political education conducted by political parties stressed to their respective ideologies. Moreover, the programs mostly are incidental, held ahead of the general election or the election of the President [8]. So, it is considered as an essential factor to construct political education preparing for good women's leadership which in turn can encourage the emergence of female candidates. Also, the political education for cadres of political parties who carried out periodically and formed is required.

The reality of low network communication among women's organisations in Indonesia and especially international network to make community development in various sectors cannot be integrated and simultaneous awakenings. In the western countries that have developed democracy, the cooperation among women's organisations has been proven to support the number of women elected in the Parliament and also in the realisation of women's welfare programs.

When each of the actors in their communities never communicates with each other, then an influential actor in his community could never transmit its power to the other. All worked individually weak remains weak. Therefore, this connection should be expanded among the countries that are in ASEAN through a social network. Starting with the development program of the community, for example, relates to the increased productivity of women in the field of economy and increased awareness of the importance of psychological health within the family by women politicians from the women politicians of Indonesia collaborate with the CMLV.

The concept of the network, explained that it started from the bond between the actors which is symmetric in both levels or intensity. The actors supplying each other with something different and they do so with higher intensity. Indeed the goal of all these groups must be agreed upon in the past and who is building norms of solidarity of fellow women can tie up and controlling the accomplishment of this goal.

The Group of ASEAN women politicians will reach the goal can be in the form of an increase in productivity in the field of economic, political and socio-cultural (three main pillars). In the economic sphere, women politicians network ASEAN together with the government of each country and working with the NGO parties to participate the realization the program alleviating needy families in their respective countries so as to realize the ASEAN community with the right economic conditions are not too far away with the economic conditions of people in other Western countries. In the political sphere, for example, ASEAN women politicians' network can do the strengthening of women's participation in politics without offending the ideology of each party involved, the interest and the main aim is to improve the quality women as citizens in different lines. With a women cadre from various strong political parties then it can educate his constituents better In the field of the socio-cultural, also the culture of each country in ASEAN can be strengthened with a helping hand of women politicians to advance tourism in ASEAN. They can invite the presence of the tourists from other countries to come to the tourist destinations in the ASEAN countries. Therefore, it is not impossible to bring foreign exchange as well as introducing the ASEAN community culture.

\section{CONCLUSION}

The conclusion is that gender sensitivity among political parties in Indonesia has not been active. Political education for the political party that has long been structured and implemented, but still limited to the derivation process of the political party. Meanwhile, the cultivation of the ideology are relatively new indicating by the political education in political parties are still very partial and tentative done before the general election. Furthermore, if there is a division of women, it is work only in their region with limited programs.

The expectation to build the ASEAN community is not small working because of its complexity to implement the three main of the ASEAN community. The link power of the women politicians in ASEAN can be optimised to realise such dream. The important thing is that the network of women politicians needs to ignore the ego of each political party. The focus is one integrated program that prospers ASEAN-poor women, left behind or marginalised, bearing in mind the ASEAN women are part of the ASEAN community as well. 


\section{REFERENCES}

[1] Ballington, Julli. Pemberdayaan Perempuan demi Partai Politik yang Lebih Kuat Panduan Praktek Terbaik Untuk Meningkatkan Partisipasi Politik Perempuan. United Nations Development Programme dan National Democratic Institute. 2011.

[2] Rahmaniah. Pendidikan Politik Berperspektif Gender sebagai Solusi Meningkatnya Keterpilihan Perempuan di Parlemen. Jurnal Repodig. http://www.untan.ac.id/pendidikanpolitik-berperspektif-gender-sebagai-solusimeningkatnya-keterpilihan-perempuan-diparlemen /. Accessed on 2 June 2018. 2016.

[3] Central Bereau of Statistic.. Statistik Politik 2016.https://media.neliti.com/media /publications/48263-ID-statistik-politik 2016.pdf. Accessed on 2 June 2018. 2016.

[4] Dessy Artina. Keterwakilan Politik Perempuan dalam Pemilu Legislatif Provinsi Riau Periode 2014-2019. Jurnal Hukum IUS QUIA IUSTUM 23,(1). January 2016: p 123 - 141. 2016.

[5] Kartika, I Made. Eksistensi Perempuan Bali Dalam Politik. Jurnal Kajian Pendidikan Widya Accarya FKIP Universitas Dwijendra ISSN NO. 2085-0018 March 2017. 2014.
[6] Purwanti, Ani. Partisipasi Perempuan pada Lembaga Legislatif Tahun 2009-2014 di Provinsi Jawa Timur. Masalah-masalah Hukum. Jilid 44. No 2. April 2015.

[7] Kertati, Indra. Implementasi Kuota 30 Persen Keterwakilan Politik Perempuan Di Parlemen. Riptek Vol. 8, No. 1, 2014, p 19 - 32. 014.

[8] Habibah, St. "Partisipasi dan Peran Perempuan Dalam Partai Politik”. Jurnal Al- Maiyyah, Volume 8 No. 2 July -December 2015. p 363-364. 2015.

[9] Salviana D. Soedarwo, Vina and Wahyudi. "An Integrative-Participative Model for Strengthening National Knowledge and Political Education to Cadres and Constituents of Political Parties", Journal on Research in Humanities and Social Science. IISTE. ISSN (Paper), 5(8), 18. 2012.

[10] Rosidawati, Imas. Keterwakilan Perempuan Di Dewan Perwakilan Rakyat Kesiapan Partai Politik \& Perempuan Indonesia Di Arena Politik Praktis, Ringkasan Penelitian, at http://www.uninus.ac.id/data/data_ilmiah/ Quota\%20Perempuan\%20di\%20DPR.pdf, accessed on 22 June 2018. 2016. 
